\title{
Factors affecting soil organic matter conservation in Mediterranean hillside winter cereals-legumes cropping systems
}

\author{
Elisa Marraccini, ${ }^{1,2}$ Marta Debolini, ${ }^{1}$ Claudia Di Bene, ${ }^{1}$ Hélène Rapey, ${ }^{3}$ Enrico Bonari ${ }^{1}$ \\ 'Land Lab, Istituto di Scienze della Vita, Scuola Superiore Sant'Anna, Pisa, Italy; \\ 2INRA, UMR 1273 Métafort, Centre Inra de Theix, Saint Genes Champanelle, France; \\ 'IRSTEA, UMR 1273 Métafort, Aubière, France
}

\begin{abstract}
Soil conservation is an important issue for farming and environmental protection in Mediterranean areas. Hillside farming systems, based on winter cereals and legumes, are common in these areas and are the target of several environmental policies. Soil organic matter (SOM) is widely used to assess the environmental performance of these cropping systems. Nevertheless, few studies have considered soil conservation practices in hillside systems in terms of implementing more effective agro-environmental policies for these areas. This paper compares the SOM conservation of different winter cereal based cropping systems within Mediterranean hillside crops/livestock farms. Seventeen cropping systems were characterised by on-farm surveys in the inland hilly area of Grosseto (Tuscany, Italy). For each cropping system, we performed a SOM balance, based on Hénin-Dupuis' equation, using either local environmental databases or data from on-farm surveys. Differences between cropping systems were analysed by the Kruskal-Wallis test. On average, the cropping systems identified did not guarantee SOM conservation and varied considerably from farm to farm, however, some practices seemed to have a positive performance, e.g. cropping systems of cattle farms. According to the literature, annu-
\end{abstract}

Correspondence: Marta Debolini, Land Lab, Istituto di Scienze della Vita, Scuola Superiore Sant'Anna, P.zza Martiri della Libertà 33, 56127 Pisa, Italy. Tel. +39.050.883504 - Fax: +39.050.883526. E-mail: m.debolini@sssup.it

Key words: agro-environmental indicators, cropping systems, on-farm surveys, soil conservation, soil organic matter balance.

Contributions: EM and MD contributed equally to this work.

Acknowledgments: EM's and MD's fieldwork was financed by a grant from the Scuola Superiore Sant'Anna (Pisa, Italy). The authors would like to acknowledge Mariassunta Galli for useful discussions and Cristiano

Tozzini for help in interpreting the soil map.

Received for publication: 23 March 2012.

Accepted for publication: 18 May 2012.

(C) Copyright E. Marraccini et al., 2012

Licensee PAGEPress, Italy

Italian Journal of Agronomy 2012; 7:38

doi:10.4081/ija.2012.e38

This article is distributed under the terms of the Creative Commons Attribution Noncommercial License (by-nc 3.0) which permits any noncommercial use, distribution, and reproduction in any medium, provided the original author(s) and source are credited. al SOM balance differs significantly depending on crop rotation length and longer crop rotations performed better than shorter ones. However, we found a local effect indicating that this better performance was influenced by local farmers' cooperatives, which to some extent counteracted the negative effect of crop rotation length. There were significant differences in the performance of dairy sheep and cattle farms (-1031 $\mathrm{kg} \mathrm{ha}^{-1} \mathrm{yr}^{-1} v s+103 \mathrm{~kg} \mathrm{ha}^{-1} \mathrm{yr}^{-1}$, respectively). This suggests that the presence of livestock did not have the same favorable effect on soil conservation in Mediterranean systems and that this factor should be more investigated. Surprisingly, in our sample, for the same crop rotation length, livestock density did not affect the annual SOM balance. Due to the high variability in local cropping systems and soil characteristics, further surveys on a larger farm sample and field soil measurement are needed to confirm these trends and validated the regional soil database. However, our results shed light on the soil conservation effects of Mediterranean hillside cropping systems of winter cereals and legumes, and could support the local implementation of agro-environmental measures.

\section{Introduction}

European landscapes are mainly agricultural. According to Eurostat (2010), agricultural land occupies around $40 \%$ of the total area, and the main agricultural system is based on winter cereals, covering $28 \%$ of the land. Over the last few decades, these systems have been greatly transformed due to: i) the abandonment and marginalisation of agricultural land, previously sustained by traditional farming practices (Caraveli, 2000; Dunjó, 2003; Rounsevell et al., 2006); ii) the extensification of land uses in less favourable areas (Bindi and Olesen, 2011; Rounsevell et al., 2006); and iii) the intensification of agricultural activities in lowlands and more productive areas (Serra et al., 2008).

In most cases these changes simplify agricultural production. In the case of the hilly Mediterranean areas, these variations have caused a transition from polycultural systems to rotation mainly based on rainfed autumn-winter cereals (MIPAAF, 2010). These dynamics have had an important environmental impact in areas that are highly vulnerable to climate change (Bindi and Olesen, 2011), because of steep slopes along with a generally low content of soil organic matter (SOM). These productive and environmental dynamics can influence soil functions, both in natural and managed ecosystems, which support plant and animal productivity, maintain air and water quality as well as human health and housing (Sombroek and Sims, 1995; Karlen et al., 1997; Pagliai, 2009). The impact of agricultural land transformation on soil functions affects: biodiversity, the hydrological cycle balance, runoff and sediment yields, soil properties (Bertora et al., 2009; Schulp and Verburg, 2009; Bindi and Olesen 2011; Di Bene et al., 2011), and par- 
ticularly the soil organic matter (SOM) conservation (Thord Karlsson et al., 2003; Sleutel et al., 2006; Grignani et al., 2007). The SOM balance, under different management strategies, is considered as one of the most widely accepted indicators of environmental sustainability of cropping and farming systems (Bockstaller et al., 1997; Silvestri et al., 2002; Castoldi and Bechini, 2006), since SOM and the carbon cycle influence the main properties and functions of soil (Holland, 2004; Pagliai, 2009; Mazzoncini et al., 2010).

The issue of SOM conservation is particularly relevant in Mediterranean areas, where agricultural soils risk progressive degradation and desertification, loss of organic matter and an undesirable decrease in fertility (Kirkby et al., 2003; Di Bene et al., 2011; Farina et $a l ., 2011$ ). This is a consequence of climatic conditions (high evapotranspiration rates, low/erratic rainfall, and intensive summer droughts), soil characteristics, and agricultural practices (traditional plough-based intensive crop production systems) (Mazzoncini et al., 2008; Alvaro-Fuentes and Paustian, 2011).

In the 1990s the European Union (EU) developed a series of economic measures to improve and stimulate best practices to guarantee soil conservation in agriculture. With the adoption of the Common Agricultural Policy (CAP) reform in 2003 (European Commission, 2003), these measures introduced the cross compliance Standards of Good Agricultural and Environmental Conditions (GAECs) (Angilieri et al., 2011). The CAP reform has been implemented in the Member States since 2005, and in Italy it was put into effect in 2006 (DM 12541/2006), listing the standard GAECs (Bazzoffi and Zaccarini Bonelli, 2011). One of the main EU objectives to preserve soil quality is by maintaining a high level of SOM. However, only a few studies have analysed and proved the effectiveness of these measures, especially in hilly and marginal agricultural systems, characterised by poorer crops (Agnoletti et al., 2011; Borrelli et al., 2011). In these areas, the studies available were mainly made in the late 1990s (Bonari et al. 1999; De Falco et al., 2000), while recent ones have focused on more intensive or specialised systems (Farina et al., 2011; Fumagalli et al., 2011). Moreover, most of these studies were made at experimental sites, fields or farms, whereas there has been a lack of research at more wide-ranging levels (e.g. local cropping and farming systems). Our aim was therefore to compare the SOM conservation of different cropping systems that are representative of the main agricultural systems of Mediterranean winter hillside crops/livestock farms. We assessed the SOM balance, based on Hénin-Dupuis' equation, of local cropping systems in order to understand factors influencing SOM conservation for implementing the post 2013 agro-environmental policies at a local level.

\section{Materials and methods}

\section{Study area}

The study area was the inland hilly area located in the Grosseto Province, southern Tuscany, Italy (latitude between $43^{\circ} 10^{\prime} \mathrm{N}$ and $42^{\circ} 20^{\prime} \mathrm{N}$; longitude between $10^{\circ} 41^{\prime} \mathrm{E}$ and $11^{\circ} 49^{\prime} \mathrm{E}$; altitude ranging from $324 \mathrm{~m}$ to $500 \mathrm{~m}$ asl) (Figure 1). Soils are quite variable but the most dominant include Lithic Xerorthents, Typic Ustorthents, Typic Dystrustepts according to USDA classification (Soil Survey Staff, 1975). They are generally not deep, with a texture ranging from silt-loam to clay and rock fragments mainly in the first layer $(0-50 \mathrm{~cm}$ depth). The climate (Figure 2) is typically Mediterranean, characterised by two main rain periods in autumn (from September to December) and spring (from March to May) and a total annual rainfall of around 800 $\mathrm{mm}$. The average temperature is $14^{\circ} \mathrm{C}$ and the warmest month is July, with a mean temperature of $23^{\circ} \mathrm{C}$.

The study area differed in terms of farming systems, which were either polycultural, mixed farming, the latter in some cases cattle-cere- al oriented and in others, sheep-grazing oriented. This coexistence of livestock and crop farms has evolved from the traditional livestockcereal systems (Pinto-Correia and Vos, 2004; Debolini et al., 2010; Marraccini et al., 2010). The main destination of agricultural products in the area are two cooperatives (Colline Amiatine and Pomonte), which differ both as for the services provided to farmers (advisory, stocking services and product promotion) and the collected products (mainly cereals and legumes in Colline Amiatine, and grains and fodder in the Pomonte) (Bonari et al., 2009). These cooperatives were setup in the first half of the last century. They were the result of the existing traditional farming systems and have had an important influence on the way current farming systems have evolved. In this area, the main issues for local agro-environmental policies are soil protection from erosion, and SOM organic matter conservation (Debolini et al., 2008; Marraccini et al., 2009). As reported by Debolini et al. (2008) the average risk of SOM loss in the area was $45 \%$ of the usable agricultural area (UAA).

\section{Soil organic matter balance}

Of the various indicators and models described in the literature to estimate the SOM balance (Mary and Guerif, 1994; Andriulo et al. 1999; Bockstaller and Girardin, 2003; Bayer et al., 2006; Castoldi and Bechini, 2009), the equation developed by Hénin and Dupuis (1945) still forms the basis of all these indicators and models (Bockstaller et al., 2008; Bertora et al., 2009; Bechini et al., 2011; Di Bene et al., 2011). This equation is based on first order kinetics and is useful for estimating how SOM evolves, for testing hypotheses and for field-scale analyses (Huggins et al., 1998). In this simple one-compartment model, the SOM balance is described by the following equation:

$$
\operatorname{SOM}_{t}=\mathrm{SOM}_{0} e^{-k_{2}} t+K_{l} O M_{i} k_{2}\left(1-e^{-k_{2}} t\right)
$$

where:

$S O M_{t}$ is the SOM stock $\left(\mathrm{kg} \mathrm{ha}^{-1}\right)$ at time $\mathrm{t}$ (year); $S O M_{0}$ is the initial SOM pool $\left(\mathrm{kg} \mathrm{ha}^{-1}\right)$ at time $\mathrm{t}=0 ; k_{2}$ is the mineralisation coefficient and refers to the annual rate of SOM loss by mineralisation; $k_{1}$ is the humification coefficient and refers to the annual rate of organic matter (OM) input incorporated in SOM; and $O M_{I}$ is the annual OM input $\left(\mathrm{kg} \mathrm{ha}^{-1}\right)$.

In eq. (1), $S O M_{0} e^{-k_{2}} \mathrm{t}$ represents the fraction of $\mathrm{SOM}_{0}$ that remains in the soil at time $\mathrm{t}$, whereas $k_{1} O M_{I} k_{2}\left(1-e^{-k_{2}} t\right)$ refers to the fraction

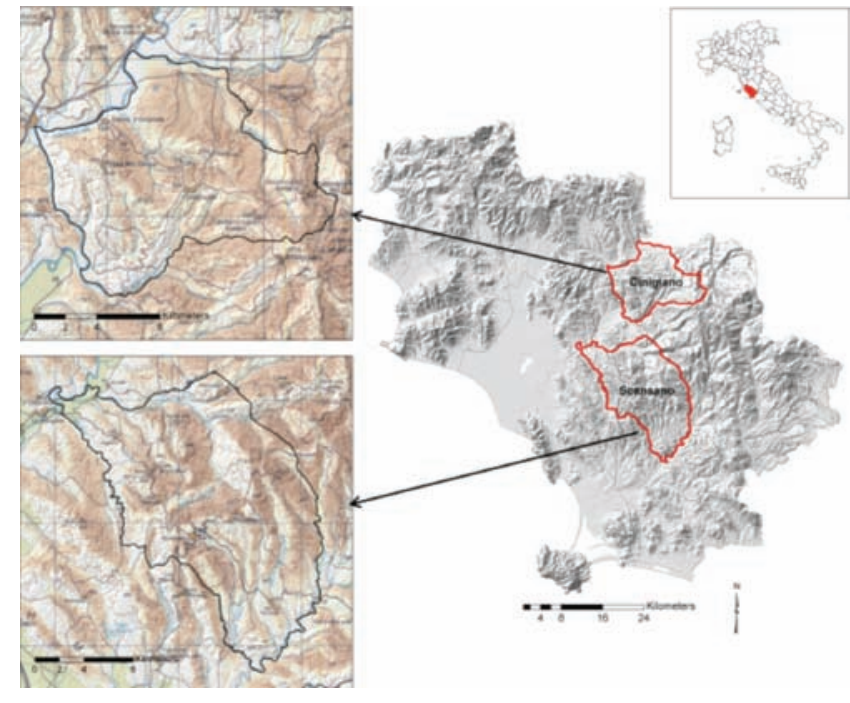

Figure 1. Localisation of the study area. 
of the SOM stock derived from the humification of organic matter input where $t=0$. SOM stock was calculated as:

$$
S O M_{\text {stock }}=\left(S O M_{c} D_{b} p A\right) / 100
$$

where:

$S O M_{c}$ is the soil organic matter concentration (\%); $D_{b}$ is the soil bulk density $\left(\mathrm{g} \mathrm{cm}^{-3}\right)$ calculated with the equation proposed by Saxton et al. (1986); $p$ is the soil depth $(0.40 \mathrm{~m})$, and $A$ is the area being considered (1 ha=10,000 $\left.\mathrm{m}^{2}\right)$.

The OM inputs $\left(O M_{I}\right)$ were: crop residues, below-ground biomass and manure or green manure. For each of these inputs, we considered a specific $k_{1}$ according to Boffin et al. (1986) and Mary and Guerif (1994) (Table 1).

The mineralisation coefficient $\left(k_{2}\right)$ is affected by climatic conditions (air temperature) and soil characteristics (texture and lime content). Following Boiffin et al. (1986) and Bockstaller and Girardin (2003), $k_{2}$ was calculated as follows:

$$
k_{2}=1200 \mathrm{f}_{\theta}[(c+200)(l+200)]
$$

where:

$f_{\theta}$ is a temperature factor given by $f_{\theta}=0.2(T-5)$, where $T$ is the average annual air temperature $\left({ }^{\circ} \mathrm{C}\right), c$ is clay content $\left(\mathrm{g} \mathrm{kg}^{-1}\right)$, and $l$ is limestone content $\left(\mathrm{g} \mathrm{kg}^{-1}\right)$. As proposed by Mary and Guerif (1994) and Bechini et al. (2011), a dimensionless correction factor of the mineralisation coefficient $(P)$ was used for the inclusion of farm soil management. $P$ was calculated as:

$$
P=p_{r} f_{r} I T_{s}
$$

where:

$p_{r}$ relates to the maximum crop plough depth $(D)$ and was calculated by the expression: $p_{r}=0.0333^{*} D ; f_{r}$ is a coefficient of crop management

Table 1. Humification coefficient $\left(k_{1}\right)$ values of the organic matter input considered (Boiffin et al., 1986; Mary and Guerif, 1994).

Input $k_{1}$ value

Cereals: barley, durum wheat, oat, perennial ryegrass, winter wheat Above-ground biomass

Below-ground biomass

Weeds grown under set-aside:

Above-ground biomass

Below-ground biomass

0.15

Leguminous: clover, faba bean, luzerne, saifoin, vicia faba

Below-ground biomass

Sunflower:

Below-ground biomass

Manure (for example, frequency of ploughing, frequency of residue incorporation, manure) as proposed by Mary and Guerif (1994) and Castoldi and Bechini (2009) (Table 2); $I$ is the mineralisation weight factor, and $T_{s}$ is the tillage factor.

The proposed methodology for the assessment of the SOM balance is illustrated in Figure 3.

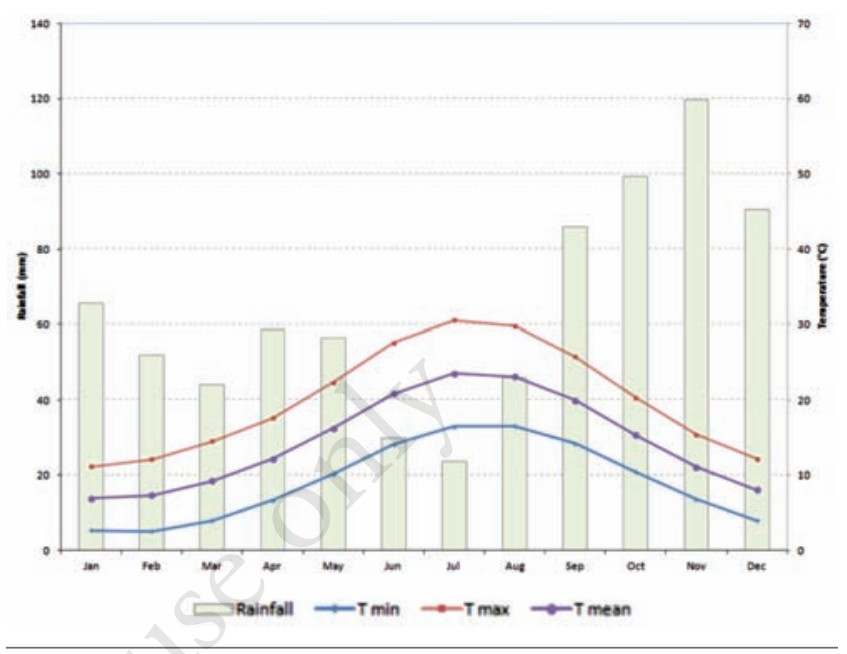

Figure 2. Diagram of Bagnouls and Gaussen showing the maximum, minimum and average temperature and the monthly rainfall calculated from 30 years of data.

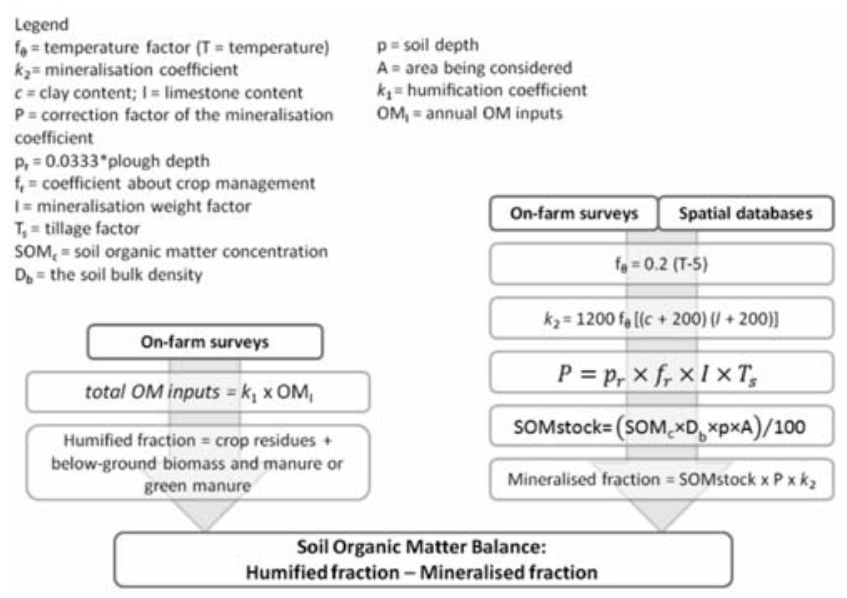

Figure 3. Overview of the overall methodology applied for the soil organic matter balance assessment.

\begin{tabular}{|c|c|c|c|c|}
\hline \multirow[b]{2}{*}{ Residues management } & \multicolumn{4}{|c|}{ Frequency of organic inputs } \\
\hline & $>10$ years & From 5 to 10 years & From 3 to 5 years & $<3$ years \\
\hline Removed or burned & 0.8 & 0.9 & 1.0 & 1.1 \\
\hline Buried once on two & 0.9 & 1.0 & 1.1 & 1.2 \\
\hline Buried every time & 1.0 & 1.1 & 1.2 & 1.3 \\
\hline
\end{tabular}

Table 2. Correction factor for $\mathrm{k}_{2}$ assessment based on frequency of residue incorporation (adapted from Mary and Guerif, 1994 and Castoldi and Bechini, 2009). 


\section{Data collection and analysis}

The data needed for the assessment of the SOM balance referred to the geo-physical environment (soil quality, average temperature, rainfall), which was obtained through existing regional spatial databases, as well as to data on farming practices that were obtained through onfarm surveys.

\section{Spatial databases}

Soil characteristics were provided by the Tuscan region (Regione Toscana, 1999a,b) since no direct soil measurements were available. This database has a 1:250,000 spatial resolution and it was obtained either by 1360 pre-existing measurements within the Tuscan Region and new 370 profiles done during a field campaign started in 1999. Following Bechini et al. (2011), we overlaid a soil map with an on-farm field database. We derived different parameters from the soil characteristics database: \% of rock fragments, soil texture, \% of SOM, \% of lime, and $\mathrm{pH}$ (Table 3 ). These parameters were average values of the different soil units recorded in each field.

The climate information was obtained from nine weather stations located in a range of $20 \mathrm{~km}$ around the study areas belonging to the network for regional climate monitoring by the Regione Toscana (formerly the Regional Agency for Agricultural Development, ARSIA). The stations collected data regarding temperature, rainfall, solar radiation and wind from 1994 to 2010 on an hourly basis. We analysed the data on a monthly basis in order to obtain a climatic description of the study areas (Figure 2) and to derive the temperature $\left(f_{\theta}\right)$ used in Eq. 3.

\section{On-farm surveys}

Data on cropping systems were obtained from on-farm surveys. Farms were identified by a preliminary local farming system assessment with experts (e.g. managers of local cooperatives, farmers' unions). We selected those farms that were the most representative of the local agricultural systems (Galli et al., 2007). A preliminary screening was done by phone to check the farmers' willingness to take part in the survey and to get some general information about their farms. Face-to-face recorded interviews were carried out at the farmsteads. The data collected for each crop sequence of the farm (length, type, location) were: tillage (date, type and depth), sowing (date, crops), fertiliser and manure applications (date, dose, nutrient concentrations), harvest (date, yield, type of harvested product), residue management, and livestock management (number, type of animal, and forage management).

When farmers could not provide the information, indirect estimation methods were applied (e.g. to estimate manure or crop yield). For the manure, we calculated the total amount of manure produced on the farm with an empirical equation that multiplies the total livestock capita, their average weight and the average amount of manure produced annually (Spallacci, 1991). For crop yield, when data were not available, we considered the average case-study production for the crop. We used this approximation particularly on hay production because of the onfarm use as fodder. When farmers were unable to inform us of their winter wheat straw production, we used a winter wheat harvest index as an indirect estimation.

Data provided by farmers were checked by simple agronomic calculations. For example, by considering an equal distribution of crops in time and space, we were able to verify when both the number and types of crop sequences provided by the farmers were correct. For manure, we compared the quantity declared, the information provided by the farmers (e.g. if they sold manure to other non livestock farms), and the calculated manure production on the basis of type and number of livestock. For forage yields, we compared the data declared with the average forage production given by experts in the preliminary interviews.

Out of a total number of 40 on-farm interviews, we selected the 10 farms that had the most cereal-oriented systems and that had a share of winter wheat on the total UAA of at least $40 \%$, which is typical of wheat-livestock farms in hilly areas in the Mediterranean. The general characteristics of these farms are illustrated in Table 4.

\section{Statistical analyses}

On-farm yearly SOM balances were compared per cropping system to find which systems and practices were more sustainable with regard to SOM conservation. Regarding the total farmland, only the permanent crops

Table 3. Topsoil characteristics in the two case studies referred to the farmstead location of the surveyed farms (source: Regione Toscana, 2005).

\begin{tabular}{lccccccccc} 
Soil class* & $\begin{array}{c}\text { Rock } \\
\text { fragments (\%) }\end{array}$ & Location & $\begin{array}{c}\text { Concerned } \\
\text { farms (\%) }\end{array}$ & $\begin{array}{c}\text { Sand } \\
(\%)\end{array}$ & $\begin{array}{c}\text { Clay } \\
(\%)\end{array}$ & $\begin{array}{c}\text { Bulk density } \\
\left(\mathrm{g} \mathrm{cm}^{-3}\right)\end{array}$ & $\begin{array}{c}\text { pH } \\
\text { CaCOntent } \\
(\%)\end{array}$ & $\begin{array}{c}\text { OM content } \\
(\%)\end{array}$ \\
MLP1_FGN1_PBL1 & 26 & All & 55 & 59 & 14 & 1.1 & 6.1 & 0 & 1.99 \\
CNI1_VDC1 & 5 & All & 25 & 13 & 23 & 1.52 & 7.8 & 18.7 & 1.20 \\
\hline CBO1_SBR1_VIV1 & 19 & Scansano & 10 & 21 & 35 & 1.35 & 7.4 & 7.4 & 1.99 \\
CPR1_POD1 & 23 & Scansano & 10 & 25 & 57 & 1.26 & 7.3 & 10.9 & 1.99 \\
\hline
\end{tabular}

*The codes represent the univocal ID of each soil units; values represent the average values among the different soil types involved. OM, organic matter.

Table 4. General characteristics of the surveyed farms in the study area.

\begin{tabular}{|c|c|c|c|c|c|c|c|}
\hline Farms & $\begin{array}{c}\text { Average farm } \\
\text { UAA (ha) }\end{array}$ & $\begin{array}{c}\text { Full-time } \\
\text { farmers (\%) }\end{array}$ & $\begin{array}{c}\text { Polyculture farming } \\
\text { system (\%) }\end{array}$ & $\begin{array}{c}\text { Ratio crops/UAA } \\
(\%)\end{array}$ & $\begin{array}{c}\text { Stocking density } \\
\text { (LU/ha) }\end{array}$ & $\begin{array}{c}\text { Min-Max } \\
\text { crop rotation } \\
\text { lenght }\end{array}$ & $\begin{array}{l}\text { Total } \\
\text { cropping } \\
\text { systems }\end{array}$ \\
\hline $\begin{array}{l}\text { Cinigiano } \\
(\mathrm{N}=6)\end{array}$ & 41 & 30 & 33 & 80 & 0.97 & $2-6$ & 10 \\
\hline $\begin{array}{l}\text { Scansano } \\
(\mathrm{N}=4)\end{array}$ & 72 & 50 & 25 & 77 & 1.85 & $1-4$ & 6 \\
\hline
\end{tabular}

UAA, usable agricultural area; LU, livestock unit. 
were excluded from the analysis, e.g. vineyards, olive groves and permanent grasslands representing on average around $2 \%$ of the farmland. SOM balance results were compared using the Kruskal-Wallis test performed with R software (R Development Core team, 2011) with different characteristics of cropping and farming systems. We used the non-parametric Kruskal-Wallis test because the data did not have a normal distribution. The characteristics of these cropping systems were first tested individually, then coupled in order to find hidden effects, for instance if the location of farmstead had an influence alongside the farming or cropping characteristics. We tested farms belonging to different cooperatives (Colline amiatine and Pomonte), thus the presence/absence of livestock on the farm, livestock density (more intensive/extensive livestock farms), types of livestock (cattle or sheep farms), ratio of winter wheat in crop rotations, and crop rotation length. On the basis of on-farms surveys we calculated livestock density, which varied depending on the presence or absence of grazing practices. With non-grazing farms, the livestock density was considered as the ratio between total livestock units and forage crop surfaces. Hence in this case, each on-farm cropping system presented the same livestock units. With grazing farms on the other hand, livestock density was calculated on the basis of the grazed surfaces and with reference to the related livestock units. Hence, in grazing farms, different cropping systems could have different livestock densities. Due to the agro-environmental measures of local policies, a density of two livestock unit (LU) per hectare is the maximum acceptable for farmers when asking for EU subsidies, thus we distinguished between farms with a livestock density of more or less than two $\mathrm{LU} \mathrm{ha}^{-1}$. For the ratio of winter wheat in each crop rotation, we considered cropping systems with less than $50 \%$ of winter wheat in the UAA, thus presenting a more diversified crop rotation, and cropping systems with more than $50 \%$ in the UAA, which are usually cultivated based on two years of continuous winter wheat. In addition, we tested differences between cropping systems with a two-year crop rotation and cropping systems with longer crop rotations $(\geq 3)$, which generally have a higher diversity and/or have partly temporary grassland, usually legumes.

\section{Results}

\section{Description of local cropping systems}

Of the 10 farms surveyed ( 5 polycultural and 5 mixed farms), we found 17 different cropping systems (Table 5). These were mainly based on winter cereals and legumes.

Of the cereals, durum wheat was the most common crop and was used both for grain and straw production. Other winter cereals were barley and oat, used both for grain and straw, but also for sheep grazing. Barley and oat are frequently inter-cropped with legumes. Sowing was generally between the end of September and the first days of November, depending on the weather conditions, and ploughing was often deep $(30-40 \mathrm{~cm})$. Minimum and no-tillage were not applied due to the clay-heavy soil. Cereal yields were quite variable ranging from 2.5 to $4.5 \mathrm{t} \mathrm{ha}^{-1}$ in winter wheat and between 3.5 and $4.5 \mathrm{t} \mathrm{ha}^{-1}$ in oat and barley. Legumes were both annual (Trifolium alexandrinum L., clover; Vicia faba L., faba bean) and perennial (Medicago sativa L., luzerne; Onobrychis viciifolia L., sainfoin) mainly used for hay production, which is used directly on-farm or sold. Total hay production varied considerably, e.g. for luzerne we found a yearly range of $3.0 \mathrm{t} \mathrm{ha}^{-1}$ between the minimum and maximum farm yields. Faba bean was used both for cattle feeding and for green manure. Manure incorporation in the first year of perennial legumes was quite common in livestock cropping systems.

The most frequent crop successions included legumes followed by winter cereals; only one crop succession also included rain-fed sunflower. After two years of continuous cereals, some farms adopted setaside. Crops were not irrigated due to the poor availability of water.

\section{Soil organic matter indicator}

\section{Cropping systems}

The cropping systems identified had an average poor performance regarding SOM conservation and a high variability (Table 6).

Table 5. General characteristics of the surveyed cropping systems (C code represent the farms and cropping system located in Cinigiano municipality, whereas the $S$ represents those located in Scansano).

\begin{tabular}{|c|c|c|c|c|c|c|c|}
\hline Farm & $\begin{array}{l}\text { Cropping } \\
\text { system }\end{array}$ & $\begin{array}{c}\text { Crop } \\
\text { succession* }\end{array}$ & $\begin{array}{l}\text { Maximum tillage } \\
\text { depth (cm) }\end{array}$ & $\begin{array}{l}\text { Livestock } \\
\text { type }\end{array}$ & $\begin{array}{l}\text { Organic matter } \\
\text { incorporation }\end{array}$ & $\begin{array}{l}\text { Dw yield } \\
\text { (t/ha) }\end{array}$ & $\begin{array}{l}\text { Hay yield } \\
\text { (t/ha) }\end{array}$ \\
\hline $\mathrm{Cl}$ & C1.1 & B/S -S-S-Dw-Fb-Dw & 30 & Cattle & Manure & 2.5 & 4.5 \\
\hline $\mathrm{C} 2$ & $\begin{array}{l}\text { C1.2 } \\
\text { C2.1 }\end{array}$ & $\begin{array}{l}\text { B/S-S-S-Dw-Dw } \\
\text { S-S-S-Dw-Ww }\end{array}$ & $\begin{array}{l}40 \\
40\end{array}$ & $\begin{array}{c}\text { Cattle } \\
\text { Dairy cattle }\end{array}$ & $\begin{array}{l}\text { Manure } \\
\text { Manure }\end{array}$ & $\begin{array}{l}3.0 \\
2.5\end{array}$ & $\begin{array}{l}4.5 \\
5.2\end{array}$ \\
\hline C3 & $\begin{array}{l}\text { C3.1 } \\
\text { C3.2 }\end{array}$ & $\begin{array}{c}\text { B/S-S-S-Dw-Dw } \\
\text { O-Dw }\end{array}$ & $\begin{array}{l}40 \\
40\end{array}$ & $\begin{array}{l}- \\
-\end{array}$ & $\begin{array}{l}- \\
-\end{array}$ & $\begin{array}{l}2.7 \\
2.7\end{array}$ & $\begin{array}{l}7.0 \\
7.0\end{array}$ \\
\hline $\mathrm{C} 4$ & C4.1 & Fb-Dw-Dw-Sa & 30 & - & Fb green manure & 3.0 & - \\
\hline $\mathrm{C} 5$ & $\begin{array}{l}\text { C5.1 } \\
\text { C5.2 }\end{array}$ & $\begin{array}{l}\text { B/S-S-S-Dw-Dw } \\
\text { L-L-L-L-Dw-Dw }\end{array}$ & $\begin{array}{l}40 \\
40\end{array}$ & $\begin{array}{c}\text { Cattle } \\
-\end{array}$ & $\begin{array}{c}\text { Manure } \\
-\end{array}$ & $\begin{array}{l}3.0 \\
3.0\end{array}$ & $\begin{array}{l}4.5 \\
4.5\end{array}$ \\
\hline C6 & $\begin{array}{l}\text { C6.1 } \\
\text { C6.2 }\end{array}$ & $\begin{array}{c}\text { Sa-Dw-B } \\
\text { L-L-L-L-Dw-Dw }\end{array}$ & $\begin{array}{l}30 \\
30\end{array}$ & - & - & $\begin{array}{l}3.0 \\
3.0\end{array}$ & $\begin{array}{c}0.7 \mathrm{Sa} \\
7.5\end{array}$ \\
\hline $\begin{array}{l}\text { S1 } \\
\text { S2 }\end{array}$ & $\begin{array}{l}\text { S1.1 } \\
\text { S2.1 } \\
\text { S2.2 }\end{array}$ & $\begin{array}{c}\text { SF-Dw } \\
\text { C-Dw } \\
\text { O-Dw }\end{array}$ & $\begin{array}{l}40 \\
40 \\
40\end{array}$ & $\begin{array}{c}- \\
\text { Sheep } \\
\text { Sheep }\end{array}$ & $\begin{array}{l}- \\
\text { Manure } \\
\text { Manure }\end{array}$ & $\begin{array}{l}3.2 \\
3.2 \\
4.5\end{array}$ & $\begin{array}{c}- \\
4.0 \\
4.5\end{array}$ \\
\hline S3 & $\begin{array}{l}\text { S3.1 } \\
\text { S3.2 } \\
\text { S3.3 }\end{array}$ & $\begin{array}{c}\text { B-O } \\
\text { L-L-L-L-O } \\
\text { S-S-S-B }\end{array}$ & $\begin{array}{l}40 \\
40 \\
40\end{array}$ & $\begin{array}{c}\text { Sheep } \\
\text { Sheep } \\
-\end{array}$ & $\begin{array}{c}\text { Manure } \\
\text { Manure } \\
-\end{array}$ & $\begin{array}{l}4.0 \\
4.0 \\
3.2\end{array}$ & $\begin{array}{l}4.5 \\
7.0 \\
7.0\end{array}$ \\
\hline S4 & S4.1 & C-Dw & 40 & - & - & 4.5 & 4.0 \\
\hline
\end{tabular}

*B, barley; C, clover; Fb, Faba bean; S, sainfoin; L, luzerne; O, oat; Sa, set-aside; SF, sunflower; Dw, durum wheat; Ww, winter wheat. 
Annual SOM balances were often negative and ranged between 897 $\mathrm{kg} \mathrm{ha}^{-1} \mathrm{yr}^{-1}$ to $-1665 \mathrm{~kg} \mathrm{ha}^{-1} \mathrm{yr}^{-1}$ in C5.1 and S2.1, respectively. Average SOM balance was $-583 \pm 628 \mathrm{~kg} \mathrm{ha}^{-1} \mathrm{yr}^{-1}$. Positive SOM balances were recorded only in three cropping systems belonging to two different farms (C2 and C5), characterised by completely different farming systems. These farming systems focused on cereal-livestock $(\mathrm{LU}=2.3)$ and polyculture $(\mathrm{LU}=0.4)$, and were managed by a full-time farmer and a retired farmer, respectively. Looking at the values of OM input (average value $540 \pm 88 \mathrm{~kg} \mathrm{ha}^{-1} \mathrm{yr}^{-1}$ ) and SOM mineralisation (average value $1255 \pm 146 \mathrm{~kg} \mathrm{ha}^{-1} \mathrm{yr}^{-1}$ ), we found a similar correlation (Spearman rank correlation) between a) SOM balance and SOM mineralisation $\left(\mathrm{r}^{2}=0.76, \mathrm{P}<0.01\right)$ and $\left.\mathrm{b}\right)$ between SOM balance and $\mathrm{OM}$ input $\left(\mathrm{r}^{2}=0.70\right.$, $\mathrm{P}<0.01$ ), indicating that there is a similar relevance of $0 \mathrm{M}$ input and SOM mineralisation in the average SOM balance.
Individual practices and factors

We tested some factors related to farm location and organisation to discriminate the SOM balance among cropping systems: belonging to a cooperative (Colline Amiatine or Pomonte), the presence/absence of livestock, the livestock type (cattle, dairy sheep), crop rotation length, and ratio of winter cereal in the crop succession. The main results are shown in Table 7. The annual SOM balance was significantly different only in the case of the livestock type and the crop rotation length. The cropping systems of cattle farms had a generally more positive SOM balance (103 $\left.\mathrm{kg} \mathrm{ha}^{-1} \mathrm{yr}^{-1}\right)$ than dairy sheep farms (-1083 $\left.\mathrm{kg} \mathrm{ha}^{-1} \mathrm{yr}^{-1}\right)$. Cropping systems presenting a shorter crop rotation had a worse SOM balance (-1228 $\left.\mathrm{kg} \mathrm{ha}^{-1} \mathrm{yr}^{-1}\right)$ than those with a longer crop rotation $\left(-434 \mathrm{~kg} \mathrm{ha}^{-1} \mathrm{yr}^{-1}\right)$. As expected, significant differences in $\mathrm{OM}$ input only concerned cropping systems of livestock farms ( $\left.681 \mathrm{~kg} \mathrm{ha}^{-1} \mathrm{yr}^{-1}\right)$ and non livestock farms (339

Table 6. Results of the soil organic matter balance for the surveyed cropping systems (C code represent the farms and cropping system located in Cinigiano municipality, whereas the $S$ represents those located in Scansano).

\begin{tabular}{|c|c|c|c|c|c|c|}
\hline Farm & $\begin{array}{l}\text { Cropping } \\
\text { system }\end{array}$ & $\begin{array}{l}\text { Crop } \\
\text { succession* }\end{array}$ & $\begin{array}{l}\text { Crop succession } \\
\text { lenght }(y)\end{array}$ & $\begin{array}{l}\text { OM inputs } \\
\left(\mathrm{kg} \mathrm{ha}^{-1} \mathrm{y}^{-1}\right)\end{array}$ & $\begin{array}{c}\text { SOM mineralisation } \\
\left(\mathrm{kg} \mathrm{ha}^{-1} \mathrm{y}^{-1}\right)\end{array}$ & $\begin{array}{l}\text { SOM balance } \\
\left(\mathrm{kg} \mathrm{ha}^{-1} \mathbf{y}^{-1}\right)\end{array}$ \\
\hline $\mathrm{Cl}$ & $\begin{array}{l}\text { C1.1 } \\
\text { C1.2 }\end{array}$ & $\begin{array}{c}\text { B/H-H-H-Dw-Fb-Dw } \\
\text { B/H-H-H-Dw-Dw }\end{array}$ & $\begin{array}{l}6 \\
5\end{array}$ & $\begin{array}{l}300 \\
523\end{array}$ & $\begin{array}{c}-752 \\
-1204\end{array}$ & $\begin{array}{l}-452 \\
-681\end{array}$ \\
\hline $\mathrm{C} 2$ & C2.1 & H-H-H-Dw-Ww & 5 & 1424 & -1004 & 421 \\
\hline $\mathrm{C} 3$ & $\begin{array}{l}\text { C3.1 } \\
\text { C3.2 } \\
\text { C4.1 }\end{array}$ & $\begin{array}{c}\text { B/H-H-H-Dw-Dw } \\
\text { O-Dw } \\
\text { Fb-Dw-Dw-Sa }\end{array}$ & $\begin{array}{l}5 \\
2 \\
4\end{array}$ & $\begin{array}{c}265 \\
97 \\
752\end{array}$ & $\begin{array}{l}-730 \\
-912 \\
-1929\end{array}$ & $\begin{array}{c}-465 \\
-815 \\
-1178\end{array}$ \\
\hline $\mathrm{C} 5$ & $\begin{array}{l}\text { C5.1 } \\
\text { C5.2 }\end{array}$ & $\begin{array}{l}\text { B/H-H-H-Dw-Dw } \\
\text { L-L-L-L-Dw-Dw }\end{array}$ & $\begin{array}{l}5 \\
6\end{array}$ & $\begin{array}{c}1109 \\
332\end{array}$ & $\begin{array}{l}-212 \\
-188\end{array}$ & $\begin{array}{l}897 \\
144\end{array}$ \\
\hline $\mathrm{C} 6$ & $\begin{array}{l}\mathrm{C} 6.1 \\
\mathrm{C} 6.2\end{array}$ & $\begin{array}{c}\text { Sa-Dw-B } \\
\text { L-L-L-L-Dw-Dw }\end{array}$ & $\begin{array}{l}3 \\
6\end{array}$ & $\begin{array}{c}53 \\
332\end{array}$ & $\begin{array}{l}-1568 \\
-1568\end{array}$ & $\begin{array}{l}-1515 \\
-1236\end{array}$ \\
\hline S1 & S1.1 & S-Dw & $2 \bigcirc$ & 421 & -1116 & -695 \\
\hline S2 & $\begin{array}{l}\text { S2.1 } \\
\text { S2.2 }\end{array}$ & $\begin{array}{l}\text { C-Dw } \\
\text { O-Dw }\end{array}$ & $\begin{array}{l}2 \\
2\end{array}$ & $\begin{array}{l}567 \\
604\end{array}$ & $\begin{array}{l}-2232 \\
-2232\end{array}$ & $\begin{array}{l}-1665 \\
-1628\end{array}$ \\
\hline S3 & $\begin{array}{l}\text { S3.1 } \\
\text { S3.2 } \\
\text { S3.3 }\end{array}$ & $\begin{array}{c}\text { B-O } \\
\text { L-L-L-L-O } \\
\text { H-H-H-B }\end{array}$ & $\begin{array}{l}2 \\
4 \\
4\end{array}$ & $\begin{array}{l}259 \\
847 \\
847\end{array}$ & $\begin{array}{l}-1665 \\
-1204 \\
-1204\end{array}$ & $\begin{array}{l}-1407 \\
-357 \\
-357\end{array}$ \\
\hline S4 & S4.1 & C-Dw & 2 & 452 & -1613 & -1160 \\
\hline
\end{tabular}

*B, barley; C, clover; Fb, Faba bean; S, sainfoin; L, luzerne; O, oat; Sa, set-aside; SF, sunflower; Dw, durum wheat; Ww, winter wheat; SOM, soil organic matter.

Table 7. Main individual practices and factors analysis affecting soil organic matter balance.

\begin{tabular}{|c|c|c|c|c|c|c|c|}
\hline & & $\begin{array}{l}\text { OM inputs } \\
\left(\mathrm{kg} \mathrm{ha}^{-1}\right)\end{array}$ & & $\begin{array}{l}\text { SOM mineralisation } \\
\qquad\left(\mathrm{kg} \mathrm{ha}^{-1}\right)\end{array}$ & & $\begin{array}{l}\text { SOM balance } \\
\left(\mathrm{kg} \mathrm{ha}^{-1}\right)\end{array}$ & \\
\hline $\begin{array}{l}\text { Cooperatives of } \\
\text { product delivery }\end{array}$ & $\begin{array}{l}\text { Colline amiatine } \\
\text { Pomonte }\end{array}$ & $\begin{array}{l}499 \pm 139 \\
571 \pm 83\end{array}$ & ns & $\begin{array}{l}-1007 \pm 575 \\
-1609 \pm 179\end{array}$ & $*$ & $\begin{array}{r}-488 \pm 773 \\
-1038 \pm 215\end{array}$ & ns \\
\hline Livestock production & $\begin{array}{c}\text { Present } \\
\text { Absent }\end{array}$ & $\begin{array}{l}681 \pm 114 \\
339 \pm 89\end{array}$ & $*$ & $\begin{array}{l}-1190 \pm 179 \\
-1348 \pm 164\end{array}$ & ns & $\begin{array}{r}-508 \pm 191 \\
-1009 \pm 137\end{array}$ & ns \\
\hline Livestock type & $\begin{array}{l}\text { Cattle } \\
\text { Sheep }\end{array}$ & $\begin{array}{l}738 \pm 225 \\
625 \pm 109\end{array}$ & ns & $\begin{array}{r}-634 \pm 205 \\
-1707 \pm 230\end{array}$ & * & $\begin{array}{r}-103 \pm 272 \\
-1083 \pm 300\end{array}$ & $*$ \\
\hline Crop rotation length & $\begin{array}{l}\geq 3 \text { years } \\
<3 \text { years }\end{array}$ & $\begin{array}{l}617 \pm 125 \\
400 \pm 78\end{array}$ & ns & $\begin{array}{l}-1051 \pm 166 \\
-1628 \pm 224\end{array}$ & ns & $\begin{array}{r}-434 \pm 219 \\
-1228 \pm 167\end{array}$ & * \\
\hline Ratio of winter cereals & $\begin{array}{c}>50 \% \\
\text { between } 40 \% \text { and } 50 \%\end{array}$ & $\begin{array}{l}510 \pm 112 \\
613 \pm 143\end{array}$ & ns & $\begin{array}{r}-1356 \pm 147 \\
-915 \pm 303\end{array}$ & ns & $\begin{array}{l}-896 \pm 187 \\
-398 \pm 403\end{array}$ & ns \\
\hline Ratio of clay in farm soils & $\begin{array}{l}\geq 30.7 \\
<30.7\end{array}$ & $\begin{array}{l}547 \pm 100 \\
488 \pm 35\end{array}$ & ns & $\begin{array}{l}-1234 \pm 164 \\
-1408 \pm 204\end{array}$ & ns & $\begin{array}{l}-561 \pm 172 \\
-744 \pm 62\end{array}$ & ns \\
\hline Ratio of SOM in farm soils & $\begin{array}{l}<2 \\
\geq 2\end{array}$ & $\begin{array}{l}542 \pm 107 \\
531 \pm 56\end{array}$ & ns & $\begin{array}{l}-1125 \pm 142 \\
-1860 \pm 372\end{array}$ & ns & $\begin{array}{l}-509 \pm 176 \\
-930 \pm 186\end{array}$ & ns \\
\hline
\end{tabular}

SOM, soil organic matter. Data are indicate as average \pm standard error; ns indicates $\mathrm{P}>0.05$. 
$\mathrm{kg} \mathrm{ha}^{-1} \mathrm{y}^{-1}$ ) because all livestock farms used manure as a fertiliser, whereas non-livestock farms used poor organic matter (Table 5). SOM mineralisation differed significantly in terms of location. In fact, it was higher in farms belonging to the Pomonte cooperative $(-1609 \pm 179 \mathrm{~kg}$ $\left.\mathrm{ha}^{-1} \mathrm{yr}^{-1}\right)$ than the Colline Amiatine cooperative $\left(-1007 \pm 182 \mathrm{~kg} \mathrm{ha}^{-1} \mathrm{yr}^{-1}\right)$ and also in livestock type: it was higher for cattle farms $(-714 \pm 173 \mathrm{~kg}$ $\left.\mathrm{ha}^{-1} \mathrm{yr}^{-1}\right)$ than for dairy sheep farms $\left(-1707 \pm 230 \mathrm{~kg} \mathrm{ha}^{-1} \mathrm{yr}^{-1}\right)$.

\section{Multiple factors}

The above factors were combined and subsequently tested in order to further discriminate among factors affecting the SOM balance of cropping systems. The main results are shown in Table 8. Annual SOM balance significantly differed for farms belonging to the Pomonte cooperative in two cases: i) between cropping systems of livestock farms (+66 kg $\left.\mathrm{ha}^{-1} \mathrm{yr}^{-1}\right)$ and non-livestock farms (-1042 $\left.\mathrm{kg} \mathrm{ha}^{-1} \mathrm{yr}^{-1}\right)$; and ii) between cropping systems with a longer crop rotation than 3 years $\left(-357 \mathrm{~kg} \mathrm{ha}^{-1} \mathrm{yr}^{-1}\right)$ and equal to or less than 3 years $\left(-1311 \mathrm{~kg} \mathrm{ha}^{-1} \mathrm{yr}^{-1}\right)$. This difference between different crop rotations was also recorded in the cropping systems belonging to the Colline Amiatine cooperative, which had a positive annual SOM balance for longer rotations $(+66 \mathrm{~kg}$ $\left.\mathrm{ha}^{-1} \mathrm{yr}^{-1}\right)$ and a negative balance for shorter rotations (-1098 $\mathrm{kg} \mathrm{ha}^{-1}$ $\left.\mathrm{yr}^{-1}\right)$. Crop rotation length also showed differences in SOM annual balance in livestock and non-livestock farms, both in the shorter and in the longer crop rotations. Surprisingly, for the same crop rotation length, livestock density was not a factor affecting annual SOM balance. Annual OM inputs significantly differed in terms of the cropping systems of farms belonging to the Colline Amiatine cooperatives depending on the ratio of winter cereals, being higher when winter cereals were between 40 and $50 \%\left(731 \mathrm{~kg} \mathrm{ha}^{-1} \mathrm{yr}^{-1}\right)$ and lower when the winter cereals ratio was over $50 \%$ ( $428 \mathrm{~kg} \mathrm{ha}^{-1} \mathrm{yr}^{-1}$ ). This was not true for the cropping systems of farms belonging to the Pomonte cooperative, which significantly differed in terms of crop rotation length. There was a higher OM input for the longest crop rotations ( $847 \mathrm{~kg} \mathrm{ha}^{-1} \mathrm{yr}^{-1}$ ) and a lower OM input for the shortest crop rotations (460 $\mathrm{kg} \mathrm{ha}^{-1} \mathrm{yr}^{-1}$ ). Surprisingly, OM inputs were unaffected by the presence of livestock when combined with other factors. However, we found that the highest livestock densities corresponded to the highest OM inputs (1039 $\left.\mathrm{kg} \mathrm{ha}^{-1} \mathrm{yr}^{-1}\right)$ only for a long crop rotation, while the shortest livestock densities corresponded to the lowest OM inputs ( $458 \mathrm{~kg} \mathrm{ha}^{-1} \mathrm{yr}^{-1}$ ). Finally, differences in SOM mineralisation were only found in the short crop rotations between the cropping systems of livestock farms $\left(-2043 \mathrm{~kg} \mathrm{ha}^{-1} \mathrm{yr}^{-1}\right)$ and the cropping systems of non-livestock farms $\left(-1213 \mathrm{~kg} \mathrm{ha}^{-1} \mathrm{yr}^{-1}\right)$.

Table 8. Main combined practices and factors analysis affecting soil organic matter balance.

\begin{tabular}{|c|c|c|c|c|c|c|}
\hline & $\begin{array}{l}\text { OM inputs } \\
\left(\mathrm{kg} \mathrm{ha}^{-1}\right)\end{array}$ & & $\begin{array}{l}\text { SOM mineralisation } \\
\left(\mathrm{kg} \mathrm{ha}^{-1}\right)\end{array}$ & & $\begin{array}{l}\text { SOM balance } \\
\left.\qquad \mathrm{kg} \mathrm{ha}^{-1}\right)\end{array}$ & \\
\hline $\begin{array}{l}\text { Pomonte } \\
\text { Winter cereals }>50 \% \\
\text { Winter cereals between } 40 \% \text { and } 50 \%\end{array}$ & $\begin{array}{l}437 \pm 16 \\
625 \pm 10\end{array}$ & ns & $\begin{array}{l}-1364 \pm 248 \\
-1707 \pm 157\end{array}$ & ns & $\begin{array}{r}-928 \pm 233 \\
-1083 \pm 147\end{array}$ & ns \\
\hline $\begin{array}{l}\text { Colline Amiatine } \\
\text { Winter cereals }>50 \% \\
\text { Winter cereals between } 40 \% \text { and } 50 \%\end{array}$ & $\begin{array}{l}428 \pm 176 \\
731 \pm 269\end{array}$ & $*$ & $\begin{array}{r}-1105 \pm 134 \\
-776 \pm 204\end{array}$ & ns & $\begin{array}{r}-678 \pm 236 \\
-45 \pm 360\end{array}$ & $\mathrm{~ns}$ \\
\hline $\begin{array}{l}\text { Pomonte } \\
\text { Presence of livestock } \\
\text { Absence of livestock }\end{array}$ & $\begin{array}{l}734 \pm 225 \\
299 \pm 124\end{array}$ & ns & $\begin{array}{r}-672 \pm 206 \\
-1341 \pm 224\end{array}$ & ns & $\begin{array}{r}66 \pm 287 \\
-1042 \pm 182\end{array}$ & $*$ \\
\hline $\begin{array}{l}\text { Colline Amiatine } \\
\text { Presence of livestock } \\
\text { Absence of livestock }\end{array}$ & $\begin{array}{l}625 \pm 109 \\
437 \pm 16\end{array}$ & ns & $\begin{array}{l}-1707 \pm 230 \\
-1364 \pm 248\end{array}$ & ns & $\begin{array}{r}-1083 \pm 299 \\
-928 \pm 233\end{array}$ & ns \\
\hline $\begin{array}{l}\text { Pomonte } \\
\text { Rotation length }>3 \text { years } \\
\text { Rotation length } \leq 3 \text { years }\end{array}$ & $\begin{array}{l}847 \pm 0 \\
460 \pm 61\end{array}$ & $*$ & $\begin{array}{l}-1204 \pm 0 \\
-1771 \pm 211\end{array}$ & ns & $\begin{array}{l}-357 \pm 0 \\
-1311 \pm 178\end{array}$ & $*$ \\
\hline $\begin{array}{l}\text { Colline Amiatine } \\
\text { Rotation length }>3 \text { years } \\
\text { Rotation length } \leq 3 \text { years } \\
\end{array}$ & $\begin{array}{l}738 \pm 225 \\
350 \pm 146\end{array}$ & ns & $\begin{array}{r}-672 \pm 206 \\
-1449 \pm 254 \\
\end{array}$ & ns & $\begin{array}{r}66 \pm 287 \\
-1098 \pm 224 \\
\end{array}$ & $*$ \\
\hline $\begin{array}{l}\text { Rotation length }>3 \text { years } \\
\text { Presence of livestock } \\
\text { Absence of livestock }\end{array}$ & $\begin{array}{l}769 \pm 156 \\
350 \pm 131\end{array}$ & ns & $\begin{array}{r}-824 \pm 162 \\
-1149 \pm 254\end{array}$ & ns & $\begin{array}{r}-55 \pm 213 \\
-1098 \pm 224\end{array}$ & $*$ \\
\hline $\begin{array}{l}\text { Rotation length } \leq 3 \text { years } \\
\text { Presence of livestock } \\
\text { Absence of livestock } \\
\end{array}$ & $\begin{array}{c}476 \pm 109 \\
238 \pm 55\end{array}$ & ns & $\begin{array}{l}-2043 \pm 189 \\
-1213 \pm 208\end{array}$ & $*$ & $\begin{array}{c}-1566 \pm 81 \\
-890 \pm 139\end{array}$ & * \\
\hline $\begin{array}{l}\text { Rotation length }>3 \text { years } \\
\text { Livestock density }>2 \\
\text { Livestock density } \leq 2\end{array}$ & $\begin{array}{r}1039 \pm 192 \\
458 \pm 117\end{array}$ & $*$ & $\begin{array}{l}-1137 \pm 67 \\
-1119 \pm 230\end{array}$ & ns & $\begin{array}{l}-98 \pm 259 \\
-561 \pm 280\end{array}$ & ns \\
\hline $\begin{array}{l}\text { Rotation length } \leq 3 \text { years } \\
\text { Livestock density }>2 \\
\text { Livestock density } \leq 2\end{array}$ & $\begin{array}{l}258 \pm 0 \\
428 \pm 89\end{array}$ & ns & $\begin{array}{l}-1665 \pm 0 \\
-1621 \pm 274\end{array}$ & ns & $\begin{array}{l}-1406 \pm 0 \\
-1193 \pm 200\end{array}$ & ns \\
\hline
\end{tabular}

OM, organic matter; SOM, soil organic matter. Data are indicate as average \pm standard error; ns indicates $P>0.05$. 


\section{Discussion}

\section{Data analysis}

The cropping systems showed a significant difference in terms of the SOM balance due to the livestock type and crop rotation length. In cattle breeding farms, there was an increase in SOM content, whereas in sheep farms, the balance was negative. This trend is also observed by Bechini et al. (2011) and Morari et al. (2006). This may be due to the different management and agricultural practices of the two farming systems. In fact, the differences between the $0 \mathrm{M}$ inputs were not significant, whereas the SOM mineralisation was significantly different and was caused by geo-physical factors and by management practices such as tillage and tillage depth. In addition, in our cattle-breeding farm, rotations were usually longer than in sheep breeding farms, where the main rotation type was based on continuous winter cereals associated or not with one-year clover. In line with West and Post (2002) and Nardi et al. (2004), the incorporation of crop residues did not seem to have a relevant effect on the SOM balance. Here, the only case when the $\mathrm{OM}$ inputs were significantly different was when we compared farms with or without livestock. This suggests that the only relevant input of $\mathrm{OM}$ was due to the manure incorporation into the soil, which has been widely observed in the literature (e.g. Boiffin et al., 1986; Accademia Nazionale di Agricoltura, 1991; Castoldi and Bechini, 2006). When we compared combined factors, with or without livestock, we found significant differences in terms of SOM balance both for short- and long-rotations. With long-rotations, the presence of livestock positively influenced the SOM balance, whereas for short-rotations livestock exerted a negative impact. This unexpected result can be explained by the fact that short-rotations were characterised by an annual tillage that did not allow for the real beneficial effect of the manure in the soil, and led to a more rapid mineralisation of labile $\mathrm{OM}$ fractions. The positive effect of tillage reduction coupled with a longrotation was observed also by Morari et al. (2006), who found in a longterm experiment comparing different crop rotations and organic fertilisation, that the SOM balance was positive only in permanent grassland and complex rotations or with the use of large quantities of livestock manure. Another unexpected result was that $\mathrm{OM}$ input was not affected by the presence of livestock when combined with other factors. The explanation may be in the nature of our case study, where also in the livestock farms, the main agricultural systems were based on rain-fed annual cereal crops. Therefore, the input on OM was also low in the presence of manure and there was a high level of OM losses due to high tillage levels. These results are in agreement with Zdruli et al. (2004) and Farina et al. (2011). In our study, the only two cases with a positive SOM balance were in the Pomonte farms with the presence of livestock and in the Colline Amiatine area when the rotation was longer than three-years. Because we ruled out any effects due to the different environmental conditions (e.g. slope, SOM content, clay content), this would seem to confirm that the management and the tillage intensity strongly influenced SOM dynamics. In fact, the most important factors influencing SOM dynamics were soil management and crop rotation, as reported by Farina et al. (2011). West and Post (2002) also found that on average the conversion from deep tillage to conservation tillage (minimum tillage and no-tillage) implied a carbon sequestration of $0.57 \mathrm{t} \mathrm{C} \mathrm{ha}^{-1} \mathrm{yr}^{-1}$.

\section{Farm data variability}

We observed an important on-farm and off-farm data variability, which was quite surprising given the different cropping systems but similar farming systems (polyculture, mixed farming-systems). This variability was influenced by farming practices, e.g. OM inputs were quite different (coefficient of variation equal to 0.67 over the total data, ranging from 0.59 to 0.67 in polyculture and in mixed farming systems, respectively) and by environmental characteristics (e.g. organic matter content, data not shown). However, the variability derived from the measured data (e.g. OM content in manure, $0 \mathrm{M} \%$ in soil) could also be higher since we worked on declared or estimated data.

In the literature we found comparable values of farm data variabilities. For example, Bockstaller et al., (1997) calculated the organic matter indicator on 13 farms (no indication of their type or their location except that they were in France and Germany) obtaining values ranging from min $3.5 ; \max 9.5$ on an indicator threshold ranging from 0 to 10. Fumagalli et al. (2011) also reported that soil organic carbon within different clusters ranged between $0.9 \%$ and $3.5 \%$, with a maximum standard deviation for clusters of $3.9 \%$. The average value was $1.7 \%$ (1.7 standard deviation). Manure applications ranged between 0 and $256 \mathrm{~kg} \mathrm{~N} \mathrm{ha}^{-1}$ depending on the farm monitored. The soil surface nitrogen indicator between the surveyed farms had an average value of 132 $\mathrm{kg} \mathrm{N} \mathrm{ha}{ }^{-1}$ and a standard deviation of 104 , with minimum values in cereal and industrial crop oriented farms $\left(27 \mathrm{~kg} \mathrm{ha}^{-1}\right)$, and maximum values in cereal farms with the use of digested manure $\left(339 \mathrm{~kg} \mathrm{ha}^{-1}\right)$.

When working in real on-farm conditions it is possible to highlight the differences both in geographical conditions and farm management, unlike in agronomic trials (Grignani et al., 2007; Bertora et al., 2009) where the plot differences were completely controlled and depended only on the variability of environmental conditions if they were located in different sites. This variability should be taken into account when working in real world conditions and can majorly affect the research results. Since it is really difficult to be exhaustive with local farms (e.g. different types of farms and farmer types, lack of data), the choice of the sample is of crucial importance. Recommendations based on a few farm samples should be avoided. In this case study, the small size of the sample (ten farms, seventeen cropping systems) was compensated for by the similar orientation of the farms and the concentration on two different locations already known to present a similar farming system and similar environmental conditions (Galli et al., 2007; Bonari et al., 2009). To overcome the small size of the sample, a new calculation will be performed on an enlarged sample (40 cropping systems), also including farms with a share of winter cereals lower than $40 \%$. Although we do not expect a significant improvement in terms of onfarm and off-farm variability, it will help to see whether the trends emerging from our results can be confirmed.

\section{Implications for policy-making}

Good Agricultural and Environmental Conditions (GAECs) are the minimum requirement to access the payment from the European Union in the framework of the new Common Agricultural Policy (CAP). At the same time the real effectiveness of the cross compliance measures has not been validated until now and there is a lack of policy evaluations (Bazzoffi and Zaccarini Bonelli, 2011). In this work we considered the SOM balance at a cropping system level as an indicator of soil management and cropping system sustainability, as a first step to evaluate the effectiveness of environmental practices applied in a certain area and the possible improvement for best environmental practices.

In this case, we can easily identify the agricultural practices that guarantee the best environmental performance, and a generalisation of this knowledge could be relevant for a local differentiation on GAECs. The main agricultural practices that appear relevant in terms of SOM conservation were the length of rotation and the breeding type. Crop rotation is also the only GAEC standard implemented in Italy for SOM conservation, however the real effectiveness of this measure is considered as low (MIPAAF, 2010). At the same time there are no policies that simultaneously implement agricultural systems and breeding activities in terms of SOM conservation.

The agricultural practices that contribute most to soil degradation 
are conventional tillage and the still widespread implementation of intensive farming systems such as continuous cereals, without the necessary supply of organic matter. Although these results have already been highlighted by the scientific community, they are not always implemented at a policy level and have been demonstrated in this work effective also in the case of Mediterranean hillside cereal-legumes cropping systems.

\section{Conclusions}

The aim of this work was to assess the SOM balance of local cropping systems on typical farms within the hillside of the province of Grosseto (Tuscany, Italy). Our results show that on the basis of the SOM balance indicator, the environmental sustainability of local cropping systems can be improved mainly through conservative cultivation techniques and the lengthening of crop rotations. The simplification of the cropping system in the Mediterranean areas, which has taken place over the last three decades, has affected the hillsides, and also the agricultural system that is still characterised by a high level of livestock production. Our results could help policy makers to provide suggestions for a more effective local implementation of agro-environmental measures to be considered in the post 2013 CAP. Future policies should try to facilitate both the maintenance of livestock-oriented farms and the lengthening of crop rotations. These two aspects are generally positively related, and constitute the right management of hillside cereal legume-based crop rotations as a key agro-ecosystem for environmental protection.

Our methodology leads to a simplified measurement of the sustainability of cropping systems in terms of SOM conservation. The main limitation of the data analysis is due to the high variability of local cropping systems and soil characteristics. For these reasons, a larger farm sample and field soil measurements are needed to confirm these trends. The used Regional soil database obtained from average values could be a source of uncertainty due to the lack of field measures. A wider analysis could be applied by considering the SOM balance not only in terms of cropping systems, but also for farming and agricultural systems, in order to assess the impact of farm management on the overall landscape.

\section{References}

Accademia Nazionale di Agricoltura, 1991. Agricoltura e Ambiente. Edagricole, Bologna, Italy.

Agnoletti M, Cargnello G, Gardin L, Santoro A, Bazzoffi P, Sansone L, Pezza L, Belfiore L. 2011. Traditional landscape and rural development: comparative study in three terraced areas in northern, central and southern Italy to evaluate the efficacy of GAEC standard 4.4 of cross compliance. Ital. J. Agron. 6(Suppl.1):e16.

Álvaro-Fuentes J, Paustian K, 2011. Potential soil carbon sequestration in a semiarid Mediterranean agroecosystem under climate change: quantifying management and climate effects. Plant Soil 338:261272.

Andriulo A, Mary B, Guerif J, 1999. Modelling soil carbon dynamics with various cropping sequences on the rolling pampas. Agronomie 19:365-377.

Angilieri V, Loudjani P, Serafini F, 2011. GAEC implementation in the EU: situation and perspectives. Ital. J. Agron. 6(Suppl.1):e2.

Bayer C, Lovato T, Dieckow J, Zanatta J, Mielniczuk J, 2006. A method for estimating coefficients of soil organic matter dynamics based on long-term experiments. Soil Till. Res. 91:217-226.

Bazzoffi P, Zaccarini Bonelli C, 2011. Cross compliance GAEC standards implemented in Italy: environmental effectiveness and strategic perspectives. Ital. J. Agron. 6(Suppl.1):e1.

Bechini L, Castoldi N, 2009. On-farm monitoring of economic and environmental performances of cropping systems: results of a 2-year study at the field scale in northern Italy. Ecol. Indic. 9:1096-1113.

Bechini L, Castoldi N, Stein A, 2011. Sensitivity to information upscaling of agro-ecological assessments: application to soil organic carbon management. Agric. Syst. 104:480-490.

Benini L, Bandini V, Marazza D, Contin A, 2010. Assessment of land use changes through an indicator-based approach: a case study from the Lamone river basin in Northern Italy. Ecol. Indic. 10:4-14.

Bertora C, Zavattaro L, Sacco D, Monaco S, Grignani C, 2009. Soil organic matter dynamics and losses in manured maize-based forage systems. Eur. J. Agron. 30:177-186.

Bindi M, Olesen JE, 2011. The responses of agriculture in Europe to climate change. Reg. Environ. Change 11:151-158.

Bockstaller C, Girardin P, 2003. Mode de Calcul des Indicateurs Agrienvironmentaux de la Methode INDIGO. Version $1.61 \mathrm{du}$ Logiciel. INRA Internal Technical Report, Colmar, France.

Bockstaller C, Girardin P, van der Werf HMG, 1997. Use of agro-ecological indicators for the evaluation of farming systems. Eur. J. Agron. 7:261-270.

Bockstaller C, Guichard L, Makowski D, Aveline A, Girardin P, Plantureux S, 2008. Agri-environmental indicators to assess cropping and farming systems. A review. Agron. Sustain. Dev. 28:139149.

Boiffin J, Kéli Zagbahi J, Sebillotte M, 1986. Systèmes de culture et statut organique des sols dans le Noyonnais: application du modèle de Hénin-Dupuis. Agronomie 6:437-447.

Bonari E, Galli M, Balducci E, Debolini M, Marraccini E, 2009. In: E. Bonari (ed.) Competitività rurale: elementi di analisi e sfide progettuali. In: Conoscenza, innovazione e sviluppo. Un futuro possibile per il sistema territorio della Provincia di Grosseto. Edizioni ISGREC, Grosseto, Italy, pp 89-135.

Bonari E, Silvestri N, Pampana S, Barberi P, 1999. La scelta del sistema colturale negli ambienti collinari dell'Italia centro-occidentale. Nota II. Aspetti economici, energetici ed ambientali. Riv. Agron. 4:220-222.

Borrelli L, Colecchia S, Troccoli A, Caradonna S, Papini R, Ventrella D, Dell'Abate MT, Galeffi C, Tomasoni C, Farina R, 2011. Effectiveness of the GAEC standard of cross compliance Crop rotations in maintaining organic matter levels in soils. Ital. J. Agron. 6(Suppl. 1):e8.

Bronick CJ, Lal R, 2005. Soil structure and management: a review. Geoderma 124:3-22.

Caraveli H, 2000. A comparative analysis on intensification and extensification in mediterranean agriculture: dilemmas for LFAs policy. J. Rural Stud. 16:231-242.

Castoldi N, Bechini L, 2006. Agro-ecological indicators of field-farming systems sustainability. I. Energy, landscape and soil management. Ital. J. Agrometeorol. 31:19-31.

Cots-Folch R, Martinez-Casasnovas JA, Ramos MC, 2009. Agricultural trajectories in a Mediterranean mountain region (Priorat, NE Spain) as a consequence of vineyard. Land Degrad. Dev. 20:1-13.

Debolini M, Galli M, Bonari E, 2008. Agro-environmental risk analysis at landscape scale: limits for a sustainable land management. Ital. J. Agron. 3(Suppl.3):321-322.

Debolini M, Galli M, Bonari E, 2010. Assessing cropping system changes in Mediterranean environments. A case study in the Grosseto Province (Tuscany, Italy). pp 939-940 in Proc. 11th Congr. Eur. Soc. Agron.m Montpellier, France.

De Falco E, Amato M, Landi G, De Franchi AS, Basso F. 2000. Valutazione di sistemi colturali sostenibili nella collina lucana. Riv. 
experiment in Central Italy. Agron. J. 100:1418-1429.

Agron. 34:337-344.

Di Bene C, Tavarini S, Mazzoncini M, Angelini LG, 2011. Changes in soil chemical parameters and organic matter balance after 13 years of ramie [Boehmeria nivea (L.) Gaud.] cultivation in the Mediterranean region. Eur. J. Agron. 35:154-163.

Dunjó G, 2003. Land use change effects on abandoned terraced soils in a Mediterranean catchment, NE Spain. Catena 52:23-37.

European Union, 2010. Agriculture in the European Union - Statistical and economic information 2010. Available from: http://ec. europa.eu/agriculture/agrista/2010/table_en/2010enfinal.pdf

Farina R, Seddaiu G, Orsini R, Steglich E, Roggero PP, Francaviglia R, 2011. Soil carbon dynamics and crop productivity as influenced by climate change in a rainfed cereal system under contrasting tillage using EPIC. Soil Till. Res. 112:36-46.

Fiener P, Auerswald K, Van Oost K, 2011. Spatio-temporal patterns in land use and management affecting surface runoff response of agricultural catchments-A review. Earth-Sci. Rev. 106:92-104.

Fohrer N, 2001. Hydrologic response to land use changes on the catchment scale. Phys. Chem. Earth PT B 26:577-582.

Fumagalli M, Acutis M, Mazzetto F, Vidotto F, Sali G, Bechini L, 2011. An analysis of agricultural sustainability of cropping systems in arable and dairy farms in an intensively cultivated plain. Eur. J. Agron. 34:71-82.

Galli M, Marraccini E, Bonari E, Debolini M, Rizzo D, 2007. Assetto agro-territoriale e qualificazione dei sistemi agricoli. Il caso della provincia di Grosseto. pp 39-40 in: Atti XXXVII Convegno Società Italiana di Agronomia, Catania, Italy.

Grignani C, Zavattaro L, Sacco D, Monaco S, 2007. Production, nitrogen and carbon balance of maize-based forage systems. Eur. J. Agron. 26:442-453.

Hénin S, Dupuis M, 1945. Essai de bilan de la matière organique des sols. Ann. Agron. 15:161-172.

Holland JM, 2004. The environmental consequences of adopting conservation tillage in Europe: reviewing the evidence. Agric. Ecosyst. Environ. 103:1-25.

Huggins DR, Buyanovsky GA, Wagner GH, Brown JR, Darmody RG, Peck RT, Lessoing GW, Vanotti MB, Bundy LG, 1998. Soil organic C in the tallgrass prairie derived region of the corn belt: effects of long-term crop management. Soil Till. Res. 47:219-234.

Karlen DL, Mausbach MJ, Doran JW, Cline RG, Harris RF, Schuman GE, 1997. Soil quality: a concept, definition, and framework for evaluation. Soil Sci. Soc. Am. J. 61:4-10.

Kirkby M, Gobin A, Irvine B, 2003. PESERA model strategy, land use and vegetation growth. PESERA EC Contract no. QLK5-CT-1999-01323.

Marraccini E, Galli M, Rapey H, Lardon S, Bonari E, 2009. Multiple agroenvironmental functions targeted by decision-makers: a compared approach in two European regions. pp 167-172 in Proc. Eur Conf. IALE, Salzburg, Austria.

Marraccini E, Galli M, Rapey H, Lardon S, Bonari E, 2010. Spatial variability of agro-environmental functions fulfilment in a Mediterranean agricultural landscape. pp 875-876 in Proc. 11th Congr. Eur. Soc. Agron., Montpellier, France.

Mary B, Guérif J, 1994. Intérets et limites des modèles de prévision de l'évolution des matières organiques et de l'azote dans le soil. Cah. Agric. 3:247-257.

Mazzoncini M, Canali S, Giovannetti M, Castagnoli M, Tittarelli F, Antichi D, Nannelli R, Cristani C, Bàrberi P, 2010. Comparison of organic and conventional stockless arable systems: a multidisciplinary approach to soil quality evaluation. Appl. Soil. Ecol. 44:124132.

Mazzoncini M, Di Bene C, Coli A, Antichi D, Petri M, Bonari E, 2008. Rainfed wheat and soybean productivity in a long-term tillage
Matson PA, Parton WJ, Power AG, Swift M, 1997. Agricultural intensification and ecosystem properties. Science 277:504-509.

MIPAAF, Ministero delle Politiche Agricole, Alimentari e Forestali, 2010. Valutazione ambientale strategica del programma attuativo nazionale "Competitività dei sistemi agricoli e rurali".

Morari F, Lugato E, Berti A, Giardini L, 1996. Long-term effects of recommended management practices on soil carbon changes and sequestration in north-eastern Italy. Soil Use Manage. 22:71-81.

Nardi S, Morari F, Berti A, Tosoni M, Giardini L, 2004. Soil organic matter properties after 40 years of different use of organic and mineral fertilizers. Eur. J. Agron. 21:257-367.

Pagliai M, 2009. Conoscenza, conservazione e uso sostenibile del suolo: aspetti fisici e morfologici. Ital J Agron 3:151-160.

Pagliai M, Vignozzi N, Pellegrini S, 2004. Soil structure and the effect of management practices. Soil Till Res. 79;131-143.

Pinto-Correia T, Vos W, 2004. Multifunctionality in Mediterranean landscapes - past and future. In: R. Jongman (ed.) The new dimensions of the European landscape, Wageningen EU Frontis Series 4:135-164.

R Development Core Team, 2011. The R manual. Available from: http://www.r-project.org/

Rounsevell MD, Reginster I, Araújo MB, Carter TR, Dendoncker N, Ewert F, House JI, Kankaanpää S, Leemans R, Metzger MJ, Schmit C, Smith P, Tuck G, 2006. A coherent set of future land use change scenarios for Europe. Agr. Ecosyst. Env. 114: 57-68.

Saxton KE, Rawls WJ, Romberger JS, Papendick RI, 1986. Estimating generalized soil water characteristics from texture. Soil Sci. Soc. Am. J. 50:1031-1036.

Schulp C, Verburg P, 2009. Effect of land use history and site factors on spatial variation of soil organic carbon across a physiographic region. Agr. Ecosyst. Env. 133:86-97.

Serra P, Pons X, Saurí D, 2008. Land-cover and land-use change in a Mediterranean landscape: a spatial analysis of driving forces integrating biophysical and human factors. Appl. Geogr. 28:189-209.

Silvestri N, Bellocchi G, Bonari E, 2002. Possibilità e limiti dell'uso degli indicatori nella valutazione agro-ambientale dei sistemi colturali. Riv. Agron. 3:232-240.

Sleutel S, De Neve S, Németh T, Tóth T, Hofman G, 2006. Effect of manure and fertilizer application on the distribution of organic carbon in different soil fractions in long-term field experiments. Eur. J. Agron. 25:280-288.

Soil Survey Staff, 1975. Soil taxonomy: a basic system of soil classification for making and interpreting soil surveys. USDA-SCS Agric. Handbook 436. US Government Print Office, Washington, DC, USA.

Sombroek WG, Sims D, 1995. Land and water bulletin No. 2. FAO Publ., Roma, Italy.

Spallacci P, 1991. La fertilizzazione con liquami zootecnici: possibilità agronomiche e compatibilità ambientali. In: Accademia Nazionale di Agricoltura (ed.) Agricoltura e Ambiente. Edagricole, Bologna, Italy, pp 280-310.

Thord Karlsson L, Andrén 0, Kätterer T, Mattsson L, 2003. Management effects on topsoil carbon and nitrogen in Swedish long-term field experiments - budget calculations with and without humus pool dynamics. Eur. J. Agron. 20:137-147.

West TO, Post WM, 2002. Soil organic carbon sequestration rates by tillage and crop rotation: a global data analysis. Soil Sci. Soc. Am. J. 66:1930-1946.

Zdruli P, Jones RJA, Montanarella L, 2004. Organic matter in the soils of Southern Europe. European Soil Bureau Technical Report. Office for Official Publications of the European Communities, Luxembourg, pp 1-16. 